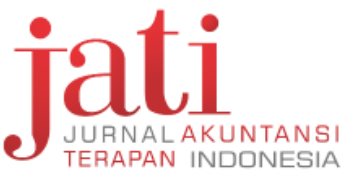

Jati: Jurnal Akuntansi Terapan Indonesia Vol 2 No 1 Hal 8-13 Maret 2019

\title{
Kinerja Keuangan Sebelum dan Sesudah Amnesti Pajak: Suatu Analisis Komparatif di Industri Otomotif
}

\author{
http://journal.umy.ac.id/index.php/jati \\ DOI: 10.18196/jati.020112
}

\section{DATA ARTIKEL:}

Diterima: 6 Mei 2019

Direviu: 23 Juli 2019

Direvisi: 16 Juli 2019

Disetujui: 1 Agustus 2019

TOPIK ARTIKEL:

Akuntansi Keuangan

\author{
NINIK CHURNIAWATI* \\ Sekolah Tinggi IImu Ekonomi (STIE) Yadika Bangil \\ *Email korespondensi: ninikchurniawati@gmail.com
}

\begin{abstract}
ABSTRAK: Tujuan dari penelitian ini untuk mengetahui perbedaan kinerja keuangan sebelum dan sesudah adanya kebi-jakan Amnesti pajak. Populasi dalam penelitian ini adalah perusahaan sub sector otomotif dan komponennya. Data yang digunakan adalah data sekunder (laporan keuangan yang dipublikasikan) melalui website www.idx.co.id. Pengujian hipotesis dilakukan dengan uji paired sample t-test. Hasil penelitian menunjukkan bahwa Terdapat perbedaan tetapi tidak signifikan kinerja keuangan Current ratio (CR), Retturn On Equity (ROE), DER, EPS dan AT baik sebelum maupun sesudah kebijakan amnesti pajak. Dari tabel uji paired sample t-test dapat diketahui bahwa CR memiliki perbedaan sebelum dan sesudah amnesti pajak yang paling tinggi, karena nilai signifikasi yang paling kecil, yaitu sebesar 0,196, dan kinerja keuangan AT memiliki perbedaan yang paling rendah karena nilai signifikasi yang paling besar, yaitu sebesar 0,893 .
\end{abstract}

Kata Kunci: Amnesti pajak, Current ratio, Retturn On Equity, Dept to equity Ratio, Earning per share, Asset turn over

\footnotetext{
ABSTRACK : The purpose of this research is to know the difference in financial performance before and after the Amnesti pajak policies. The population in this research is the company sub-sectors automotive and its components. The data used are secondary data (the published financial reports) through the website wwww.idx.co.id. Hypothesis testing is done by testing paired sample t-test. The se-
}

results showed that there is a difference but not significant financial performance Current ratio (CR), Return On Equity (ROE), DER, EPS and AT both before and after the amnesti pajak policy. From table test paired sample t-tests can be noted that CR has difference before and after the amnesti pajak are the highest, because the value of the least significance, namely of 0.196 , and financial performance AT least has the distinction because of the value greatest significance, namely of 0.893.

Keywords: Amnesti pajak, Current ratio, Retturn On Equity, Dept to equity Ratio, Earning per share, Asset turn over

\section{SITASI ARTIKEL:}

Churniawati, N., (2019). Kinerja Keuangan Sebelum dan Sesudah Amnesti Pajak: Suatu Analisis Komparatif di Industri Otomotif. Jati: Jurnal Akuntansi Terapan Indonesia, 2(1), 8-13

\section{PENDAHULUAN}

Dalam rangka peningkatan pertumbuhan ekonomi indonesia seharusnya diimbangi dengan naikknya penerimaan pajak dan menambah ketersediaan likuiditas dalam negeri. Di sisi lain, masih banyaknya kecurangan yang dilakukan warga negara indonesia tentang pajak, salah satunya dengan menyimpan harta mereka diluar negeri dan tidak melaporkan harta mereka dalam SPT tahunannya.

Selain itu, keberhasilan pembanguna nasional keberhasilan pembangunan nasioanl sangat didukung oleh pembiayaan yang berasal dari masyarakat, yaitu penerimaan pembayaran pajak. Agar peran serta ini dapat terdistribusikan dengan merata tanpa ada pembeda, perlu diciptakan system perpajakanyang lebih berkeadilan dan berkepastian hukum. 
Oleh karena itu dibuat suatu kebijakan yang dapat mengalihkan harta warga negara indonesia kedalam wilayah Negara Kesatuan RI sekaligus menjamin keamanannya jika mereka mau melakukan pengalihan dan pengungkapan hartanya. Kebijakan ini diharapkan mampu mengurangi kemungkinan penyembunyian kekayaan di luar wilayah Negara Kesatuan RI karena semakin transparannya sektor keuangan yang global dan meningkatnya pertukaran informasi antar Negara.

Kebijakan Pengampunan Pajak ini dilakukan untuk menghapus pajak yang seharusnya terutang, tanpa sanksi administrasi dan sanksi pidana dibidang perpajakan dengan cara mengungkapkan harta tersebut dan membayar uang tebusan. Dengan adanya kebijakan ini dapat membiayai program jangka pendek negara setelah diterimanya Uang Tebusan. Selain itu negara akan mendapat tambahan penerimaan pajak dari aktifitas ekonomi yang hartanya telah dialihkan dan di investasikan didalam wilayah Negara kesatuan RI. Dari aspek yuridis, peraturan tentang Pengampunan Pajak (Disingkat UU TA) No. 11/2016 pasal 23 A UUD Negara RI tahun 1945 tentang penghapusan pajak terutang, sanksi administrasi dan sanksi pidana dibidang perpajakan. Penelitian Nugeraha 2016 menunjukkan bahwa Current Ratio dan Return On equity Berpengaruh signifikan antara sebelum dan sesudah dilakukaknya Amnesti Pajak. Menurut Ariani 2018 juga menunjukkan bahwa kinerja keuangan Rasio Likuiditas dan Rasio Profitabilitas berpengaruh yang signifikan antara sebelum dan sesudah dilakukanya Amnesti Pajak.

Definisi Pajak. Menurut Pohan (2014:141) "pajak adalah suatu pungutan resmi berdasarkan peraturan perundang-undangan perpajakan yang dikenakan kepada wajib pajak ats penghasilan global yang diterima atau diperolehnya dalam suatu tahun pajak, guna membiayai belanja Negara dalam penyelenggaraan pemerintahan. Karakteristik pajak meliputi arus uang (bukan barang) dari rakyat ke kas Negara, pajak dipungut berdasarkan undangundang (dapat dipaksanakan), tidak ada timbal balik secara langsung dan digunakan untuk membiayai pengeluaran secara umum demi kemakmuran rakyat. Halim (2016:2)

Sistem Pemungutan Pajak. Sistem pemungutan pajak dibedakan menjadi 3 (tiga), yaitu self assessment system (system menghitung pajak sendiri) adalah suatu sistem yang mana wajib pajak dapat melaksanakan kewajiban dan hak (menghitung) perpajakannya sendiri. Official assessment system (pemungutan dengan system ketetapan) adalaha suatu system yang mana wajip pajak diberikan wewenang untuk menentukan besarnya pajak yang terutang. Withholding Tax System yaitu suatu system pemungutan pajak, yang memberikan wewenang pada pihak tertentu atau pihak ketiga (withholder) untuk memotong atau memungut pajak yang terutang berdasarkan prosensi tertentu terhadap jumlah pembayaran yang dilakukan dengan penerima penghasilan. Tata cara ini akan berhasil dengan baik bila masyarakat/wajib pajak memiliki kemampuan dan disiplin pajak serta kepatuhan pajak yang tinggi dalam melaksanakan kewajiban perpajakan. Pohan (2018:250).

Pengampunan Pajak (Tax Amnesty). Dalam rangka melakukan optimalisasi penerimaan Negara dari sektor pajak, meningkatkan kesadaran wajib pajak dan meningkatkan kepatuhan dalam membayar pajak di masyarakat (tax awareness and tax compliance), serta memperluas basis subjek pajak untuk mendukung penerimaan pajak yang optimal dan berkelanjutan, maka tahun 2016 pemerintah RI mengeluarkan kebijakan perpajakan yang disebut dengan Amnesti Pajak melalui Undang-Undang Pengampunan Pajak No. 11 tanggal 1 Juli tahun 2016. Kebijakan pengampunan pajak (Tax Amnesty) adalah kebijakan penghapusan atas pajak terutang, sanksi administrasi, dan pidana perpajakan yang dilakukan dengan membayar sejumlah uang tebusan (sesuai tarif yang berlaku).

Kinerja keuangan. Kinerja keuangan adalah parameter keberhasilan suatu perusahaan dalam mencapai tujuan perusahaan dalam periode waktu tertentu, pohan (2017:480). Kinerja keuangan merupakan suatu analisis untuk menilai apakah suatu perusahaan mampu melakukan aktifitas sesuai aturan pelaksanaan keuangan. Selain itu untuk mengetahui dan mengevaluasi tingkat keberhasilan suatu perusahaan berdasarkan aktivitas keuangannya. Untuk memperbaiki kegiatan operasional yang mampu bersaing maka perlu dilakukan kinerja keuangan perusahaan pada periode tertentu. Menghitung, mengukur atau menginterprestasikan dan memberikan solusi adalah cara untuk menganalisis kinerja keuangan.

Tujuan dan manfaat menilai kinerja keuangan antara lain untuk mengetahui tingkat likuiditas perusahaan (kemampuan perusahaan membayar kewajiban keuangannya), mengetahui tingkat profitabilitas perusahaan (kemampuan perusahaan dalam memperoleh laba), mengetahui seberapa besar nilai pasar saham perusahaan dibanding dengan nilai buku, Semakin tinggi maka semakin baik prospek perusahaan dalam perspektif investor), mengetahui kekuatan perusahaan dalam membiaya usahanya. Kemampuan perusahaan dengan hanya mengandalkan modal sendiri (equity financing) seringkali terbatas, sehingga pembiayaan dengan hutang ditempuh untuk mendukung pembiayaan equity dan mengetahui seberapa efektif manajemen 
perusahaan mengelola aktivanya. Rasio ini mengukur seberapa besar kecepatan aset-aset perusahaan dikelola atau "diputar" dalam rangka melakukan aktivitas bisnisnya.

Analisis rasio keuangan. Analisis rasio keuangan adalah menjelasan hubungan jumlah dalam suatu laporan keuangan. Analisis laporan keuangan bertujuan untuk membandingkan pos-pos dalam laporan keuangan yang hasil analisisnya digunakan sebagai pedoman dalam mengambil keputusan.

Berdasarkan uraian di atas, maka dapat disusun hipotesis penelitian sebagai berikut: H1: Terdapat perbedaan kinerja keuangan current ratio sebelum dan sesudah kebijakan tax amnesty pada perusahaan otomotif dan komponennya.

$\mathrm{H} 2$ : Terdapat perbedaan kinerja keuangan return on Equity sebelum dan sesudah kebijakan tax amnesty pada perusahaan otomotif dan komponennya

H3: Terdapat perbedaan kinerja keuangan Dept to equity Ratio sebelum dan sesudah kebijakan tax amnesty pada perusahaan otomotif dan komponennya.

H4: Terdapat perbedaan kinerja keuangan Earning per share sebelum dan sesudah kebijakan tax amnesty pada perusahaan otomotif dan komponennya.

H5: Terdapat perbedaan kinerja keuangan Asset turnover sebelum dan sesudah kebijakan tax amnesty pada perusahaan otomotif dan komponennya.

\section{METODE PENELITIAN}

Penelitian ini tergolong penelitian comparative yaitu riset antara 2 variabel yang menghasilakn perbandingan suatu output pada waktu yang berbeda, (sugiono, 2016:36). Lokasi penelitian ini diperusahaan yang terdaftar di BEI subsektor otomotif dan komponennya yang datanya di peroleh dari website www.idx.co.id. Penelitian ini dimulai dari bulan Desember 2018 sampai dengan Maret 2019. Data yang digunakan dalam penelitian ini adalah data sekunder. Data sekunder adalah penelitian arsip yang memuat kejadian masa lalu. Dalam penelitian ini peneliti mengumpulkan data melalui teknik dokumentasi, yaitu mengumpulkan data sekunder dari laporanlaporan keuangan perusahaan subsektor otomotif dan komponennya. Metode analisi yang digunakan adalah uji beda, yakni menggunakan uji untuk 2 sample yang berpasangan (paired sample t-test).

Penelitian ini terdiri dari variabel bebas atau variabel independent, prediktor, variabel stimulus, actecedent yaitu variabel yang mempengaruhi perubahan variabel terikat (current ratio, return on Equity, Dept to equity Ratio, Earning per share dan Asset turnover) dan Variabel terikat, dependen yaitu variabel yang dipengaruhi variabel bebas (Tax Amnesty).

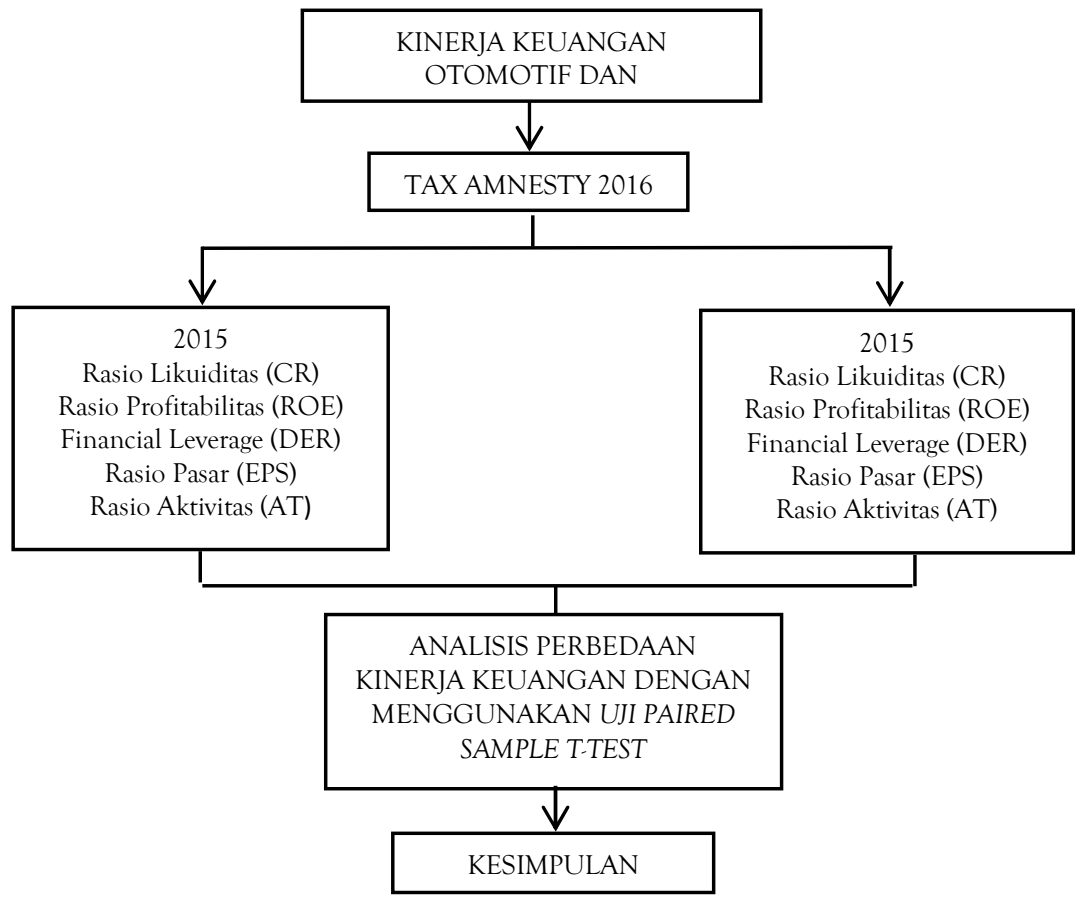

Gambar 1. Kerangka Konseptual

Agar pelaksanaan penelitian ini sesuai yang diharapkan maka perlu dipahami unsur penelitian ini yaitu:
Current ratio. Current ratio merupakan rasio yang membandingkan akitva lancar dan hutang lancar (mengukur kemampuan perusahaan 
membayar hutang), Semakin besarnya rasio ini dapat diartikan perusahaan semakin likuid. Hery (2017:287)

$$
\text { Current ratio }=\frac{\text { curent agat }}{\text { current liabilitisa }}
$$

Return On Equity (ROE). Return on equity mengukur seberapa besar keuntungan bersih untuk dibagikan ke pemegang saham. Rasio ini mengukur berapa rupiah keuntungan yang dihasilkan oleh modal sendiri.

$$
\text { ROE }==\frac{\text { Net heome }}{\text { Stoekholder sEquity }}
$$

Debt to equity. Debt to equit ratio merupakan perbandingan antara besarnya total hutang dengan total equity. Dengan rasio ini dapat melihat kemampuan pemilik perusahaan untuk melunasi hutangnya. Jika nilai perusahaan dapat digambarkan sebuah lingkaran pizza, dan jika pizza tersebut dibagi dua artinya perusahaan dibiayai modal sendiri/equity dan hutang/debt masing-masing sebesar $50 \%$. Komposisi antara equity dengan debt ini menunjukkan struktur pembiayaan atau struktur modal perusahaan yaitu menunjukkan dari sumber apa perusahaan didirikan atau dibelanjai. Semakin besar DER maka semakin besar risiko perusahaan. Kemampuan perusahaan untuk membayar hutang ini sangat tergantung dari arus kas perusahaan.

$$
\text { Debt to equity }=\frac{\text { Total Debt }}{\text { STotal Equity }}
$$

Earning per share (EPS). EPS menunjukkan bagian laba untuk pemegang saham (per lembar saham yang dimiliki). Besar kecilnya EPS dipengaruhioleh Laba bersih dan jumlah lembar saham perusahaan. Jika perusahaan menambah modal saham dengan mengeluarkan lembar saham baru sementara laba tidak berubah maka EPS akan semakin kecil.

$$
\text { EPS }=\frac{\text { Net Income }}{\text { Number Of outgtanding stook }}
$$

Assets turnover. Asets turnover mengukur seberapa efektif aktiva perusahaan mampu menghasilkan pendapatan operasional (pendapatan utama perusahaan). Bagi sebuah perusahaan perhotelan, pendapatan utama berasal sewa kamar hotel. Jika hotel tersebut menginvestasikan pendapatan dananya dalam surat-surat berharga di pasar modal, maka pendapatan dari surat berharga tersebut bukan merupakan pendapatan operasional. Semakin tinggi asets turn over artinya

kinerja keuangan baik sebelum maupun sesudah tax amnesty berbeda tetapi tidak signifikan.

Hasil uji hipotesis 1 disimpulkan bahwa ada perbedaan tetapi tidak signifikan kinerja keuangan semakin baik aktiva tersebut dalam menghasilkan pendapatan.

Assets turnover $=\frac{\text { NenTotal Operating Revenus }}{\text { Total Assets }}$

\section{HASIL DAN PEMBAHASAN}

Data Deskriptif. Penelitian yang dilakukan menggunakan data sekunder sebagai sumber data, jenis penelitian yang dilakukan kuantitatif, dimana peneliti menggunakan suatu event, yaitu ketika pemerintah mengeluarkan kebijakan tax amnesty yang dilakukan pada tahun 2016, dan peneliti ingin mengetahui apakah dengan kebijakan pemerintah tersebut terdapat perbedaan yang signifikan atau tidak pada kinerja keuangan. Berikut data deskriptif yang digunakan oleh peneliti, yang terdiri dari 13 perusahaan, dan yang dianalisis adalah kinerja keuangan perusahaan tersebut yang terdiri dari 5 kinerja keuangan sebelum dan sesudah adanya kebijakan Tax Amnesty. Berikut akan dijelaskan di tabel 1.

Uji Normalitas. Peneliti menggunakan uji beda (paired sample t-test) untuk menguji data yang hasilnya digunakan untuk menguji hipotesis, sebelum dilakukan uji beda data harus diuji normalitas, setelah data berdistribusi normal, langkah selanjutnya dilakukan uji beda (paired sample t-test).

Uji normalitas kinerja keuangan sebelum tax amnesty. Hasil uji normalitas kinerja keuangan sebelum tax amnesty di tabel 2. Data dikatakan berdistribusi normal jika nilai Asymp. Sig. (2-tailed) diatas 0,05 (signifikasi > 0,05). Dari tabel 2 diketahui nilai Asymp. Sig. (2-tailed) untuk seluruh data sebelum kebijakan tax amnesty lebih dari 0.05, maka data ini lolos uji normalitas (berdistribusi normal).

Uji normalitas kinerja keuangan sesudah tax amnesty. Hasil uji normalitas untuk kinerja keuangan sesudah adanya kebijakan Tax Amnesty di tabel 3. Untuk kinerja keuangan sesudah tax amnesty seluruh data berdistribusi normal, pada tabel 3 dapat diketahui seluruh nilai Asymp. Sig. (2-tailed) lebih dari 0,05. Maka dapat disimpulkan untuk data sebelum dan sesudah tax amnesty berdistribusi normal, sehingga uji beda dapat dilakukan.

Uji Hipotesis. Untuk menjawab hipotesis peneliti menggunakan uji beda (paired sample ttest) sebagai alat untuk menganalisis, berikut hasil dari uji beda (paired sample t-test). Pada tabel 4 dapat diketahui bahwa seluruh nilai signifikasi pada

Current ratio (CR) sebelum dan sesudah adanya kebijakan tax amnesty, hal ini dapat diketahui pada tabel 4 nilai sig (2-tailed) sebesar 0,196. Nilai tersebut $>0,05$ (sig.>0,05). Hasil uji hipotesis 2 
disimpulkan bahwa ada perbedaan tetapi tidak signifikan kinerja keuangan Retturn On Equity (ROE) sebelum dan sesudah adanya kebijakan tax amnesty, hal ini dapat diketahui pada tabel 4 nilai sig (2-tailed) sebesar 0,238. Nilai tersebut $>0,05$ (sig.>0,05). Hasil uji hipotesis 3 disimpulkan bahwa ada perbedaan tetapi tidak signifikan kinerja keuangan DER sebelum dan sesudah kebijakan tax amnesty, hal ini dapat diketahui pada tabel 4 nilai sig (2-tailed) sebesar 0,273. Nilai tersebut $>0,05$ (sig.>0,05). Hasil uji hipotesis 4 disimpulkan bahwa ada perbedaan tetapi tidak signifikan kinerja keuangan EPS sebelum dan sesudah adanya kebijakan tax amnesty, hal ini dapat diketahui pada tabel 4 nilai sig (2-tailed) sebesar 0,242. Nilai tersebut >0,05 (sig.>0,05). Hasil uji hipotesis 5 disimpulkan bahwa ada perbedaan tetapi tidak signifikan kinerja keuangan AT sebelum dan sesudah adanya kebijakan tax amnesty, hal ini dapat diketahui pada tabel 4 nilai sig (2-tailed) sebesar 0,893 . Nilai tersebut $>0,05$ (sig.>0,05).

Dari tabel uji paired sample $t$ test dapat diketahui bahwa CR memiliki perbedaan yang paling tinggi, karena nilai signifikasi yang paling kecil, yaitu sebesar 0,196 sedangkan pada penelitian Nugeraha menyatakan bahwa terdapat pengaruh yang signifikan yang dikarenakan adayanya peningkatan investasi. AT memiliki perbedaan yang paling rendah karena nilai signifikasi yang paling besar, yaitu sebesar 0,893 , berbeda dengan penelitian ariani yang menyatakan bahwa terdapat pengaruh yang signifikan karena adanya peningkatan aktivitas perusahaan setelah adanya kebijakan ini.

Tabel 1. Data deskriptif

\begin{tabular}{|c|c|c|c|c|c|c|c|c|c|c|}
\hline No & $\begin{array}{c}\text { CR } \\
(2015)\end{array}$ & $\begin{array}{c}\text { ROE } \\
\text { (2015) }\end{array}$ & $\begin{array}{c}\text { DER } \\
\text { (2015) }\end{array}$ & $\begin{array}{c}\text { EPS } \\
(2015)\end{array}$ & $\begin{array}{c}\text { AT } \\
(2015)\end{array}$ & $\begin{array}{c}\text { CR } \\
(2017)\end{array}$ & $\begin{array}{c}\text { ROE } \\
\text { (2017) }\end{array}$ & $\begin{array}{c}\text { DER } \\
\text { (2017) }\end{array}$ & $\begin{array}{c}\text { EPS } \\
(2017)\end{array}$ & $\begin{array}{c}\text { AT } \\
(2017)\end{array}$ \\
\hline 1 & 137,93 & 12,43 & 0,94 & 357,31 & 0,7505 & 122,86 & 14,82 & 0,89 & 466,390 & 0,6969 \\
\hline 2 & 132,29 & 3,18 & 0,41 & 66,10 & 0,8176 & 155,87 & 5,09 & 0,40 & 114,410 & 0,9178 \\
\hline 3 & 180,65 & 6,87 & 0,60 & 339,15 & 0,7122 & 238,89 & 11,32 & 0,40 & 672,110 & 0,7940 \\
\hline 4 & 93,66 & $-0,2$ & 1,15 & $-39,67$ & 1,2940 & 86,07 & $-1,67$ & 1,31 & $-29,550$ & 1,3029 \\
\hline 5 & 177,81 & $-5,81$ & 2,25 & $-89,91$ & 0,7408 & 162,99 & 0,79 & 2,20 & 12,920 & 0,7777 \\
\hline 6 & 93,59 & $-0,34$ & 2,71 & $-16,54$ & 0,7280 & 83,77 & $-0,69$ & 2,38 & $-39,640$ & 0,4895 \\
\hline 7 & 223,13 & 0,1 & 0,33 & 1,44 & 0,6498 & 512,54 & 5,3 & 0,14 & 173,750 & 0,8083 \\
\hline 8 & 78,97 & $-15,6$ & 1,78 & $-664,72$ & 0,2400 & 520,65 & 82,94 & 0,16 & 1806,850 & 0,3839 \\
\hline 9 & 128,52 & $-7,78$ & 0,73 & $-42,76$ & 0,3960 & 94,98 & $-2,4$ & 0,95 & $-11,910$ & 0,3150 \\
\hline 10 & 104,73 & 1,98 & 1,54 & 20,63 & 0,6383 & 117,37 & 2,32 & 1,16 & 26,970 & 0,5675 \\
\hline 11 & 100,5 & 0,89 & 1,13 & 9,18 & 0,3067 & 95,71 & $-0,48$ & 1,28 & $-4,600$ & 0,2259 \\
\hline 12 & 239.38 & 32,03 & 0,54 & 297,03 & 1,2625 & 373,91 & 30,38 & 0,34 & 86,730 & 1,3669 \\
\hline 13 & 439,1 & 12,84 & 0,21 & 41,68 & 0,9347 & 312,7 & 13,5 & 0,65 & 41,500 & 0,8813 \\
\hline
\end{tabular}

Tabel 2. Uji Normalitas kinerja keuangan sebelum tax amnesty

\begin{tabular}{llccccc}
\hline Keterangan & & CR & ROE & DER & EPS & AT \\
& & $(2015)$ & $(2015)$ & $(2015)$ & $(2015)$ & $(2015)$ \\
\hline $\mathrm{N}$ & 13 & 13 & 13 & 13 & 13 \\
\hline Normal Parameters $^{\mathrm{a}}{ }^{2}$ & Mean & 163.8662 & 3.1223 & 1.1015 & 21.4554 & .728546 \\
& Std. Deviation & 97.01838 & 11.61317 & .77251 & 255.79390 & .3159296 \\
\hline Kolmogorov-Smirnov Z & .796 & .686 & .603 & .918 & .594 \\
\hline Asymp. Sig. (2-tailed) & .551 & .734 & .860 & .368 & .873 \\
\hline
\end{tabular}


Tabel 3. Uji Normalitas Kinerja Keuangan Sesudah Tax Amnesty

\begin{tabular}{|c|c|c|c|c|c|c|c|c|}
\hline \multirow[t]{2}{*}{ Keterangan } & \multirow[t]{2}{*}{ Mean } & \multirow[t]{2}{*}{$\begin{array}{c}\text { Std. } \\
\text { Deviation }\end{array}$} & \multirow{2}{*}{$\begin{array}{l}\text { Std. } \\
\text { Error } \\
\text { Mean }\end{array}$} & \multicolumn{2}{|c|}{$\begin{array}{l}\text { 95\% Confidence } \\
\text { Interval of the } \\
\text { Difference }\end{array}$} & \multirow[t]{2}{*}{$\mathrm{t}$} & \multirow[t]{2}{*}{$\mathrm{df}$} & \multirow[t]{2}{*}{$\begin{array}{l}\text { Sig. (2- } \\
\text { tailed) }\end{array}$} \\
\hline & & & & Lower & Upper & & & \\
\hline Pair 1 CR(2015) - CR(2017) & -5.754 & 151.582 & 42.041 & -149.143 & 34.058 & -1.369 & 12 & .196 \\
\hline Pair 2 ROE (2015) - ROE (2017) & -9.279 & 26.967 & 7.479 & -25.575 & 7.017 & -1.241 & 12 & .238 \\
\hline Pair 3 DER(2015) - DER(2017) & .158 & .497 & .138 & -.142 & .459 & 1.150 & 12 & .273 \\
\hline Pair 4 EPS(2015) - EPS(2017) & -2.336 & 683.774 & 189.645 & -646.817 & 179.584 & -1.232 & 12 & .242 \\
\hline Pair 5 AT(2015 - AT(2017) & -4.346 & .114 & .032 & -.073 & .064 & -.138 & 12 & .893 \\
\hline
\end{tabular}

Tabel 4. Uji Pair Sample T-Test

\begin{tabular}{llrrrrr} 
Keterangan & \multicolumn{1}{c}{ CR } & ROE & DER & EPS & \multicolumn{1}{c}{ AT } \\
& & $(2017)$ & $(2017)$ & $(2017)$ & $(2017)$ & \multicolumn{1}{c}{$(2017)$} \\
\hline $\mathrm{N}$ & 13 & 13 & 13 & 13 & 13 \\
\hline Normal Parameters $^{\mathrm{a}}$ & Mean & 221.4085 & 12.4015 & .9431 & 255.07154 & .732892 \\
\cline { 2 - 8 } & Std. Deviation & $1.59031 \mathrm{E} 2$ & 23.09743 & .72113 & $5.118743 \mathrm{E} 2$ & .3459141 \\
\hline Kolmogorov-Smirnov Z & .933 & 1.098 & .573 & 1.198 & .514 \\
\hline Asymp. Sig. (2-tailed) & .349 & .179 & .898 & .113 & .954 \\
\hline
\end{tabular}

\section{SIMPULAN}

Berdasarkan hasil analisis data maka dapat disimpulkan bahwa terdapat perbedaan tetapi tidak signifikan kinerja keuangan Current Ratio (CR) sebelum dan sesudah adanya kebijakan tax amnesty. Terdapat pula perbedaan tetapi tidak signifikan kinerja keuangan Retturn On Equity (ROE) sebelum dan sesudah adanya kebijakan tax amnesty. Selain itu, terdapat perbedaan tetapi tidak signifikan kinerja keuangan DER sebelum dan sesudah adanya kebijakan tax amnesty. Terdapat perbedaan tetapi tidak signifikan kinerja keuangan EPS sebelum dan sesudah adanya kebijakan tax amnesty serta terdapat perbedaan tetapi tidak signifikan kinerja keuangan AT sebelum dan sesudah adanaya kebijakan tax amnesty. Kondisi kinerja keuangan mengalami penurunan tetapi tidak signifikan jika dibandingkan dengan sebelum mengikuti program Tax Amnesty. Hal ini mengindikasi bahwa kealpaah perusahaan dalam pelaporan perpajakan khususnya perusahaan otomotif dan komponennya tidak berdampak pada kinerja keuangan. Peneliti membatasai objek penelitian pada perusahaan otomotif dan komponennya yang ter-daftar d BEI. Penelitian ini membahas tentang perbedaan kinerja keuangan sebelum dan sesudah adanya kebijakan Tax Amnesty sehigga hasil penelitian ini tidak bisa digeneralisasikan pada perusahaan selain industri otomotif. Saran bagi peneliti selanjutnya agar melakukan penelitian dengan objek yang berbeda, dengan jumlah sampel yang lebih banyak, serta dapat menganalisis dengan periode yang lebih luas. Selain itu, hendaknya ketika pemerintah me-ngeluarkan kebijakan baru dapat memberi efek positif yang signifikan bagi perusahaan.

\section{DAFTAR PUSTAKA}

Ariani, 2018. Analisis Perbandingan Kinerja Keuangan Sebelum Dan Sesudah Diberlakunya Tax Amnesty Periode Ketiga Tahun 2016 Pada Perusahaan Sub Sektor Tekstil Dan Garmen Yang Terdaftar Di BEI. E-JRA Vol.07. Diakses Pada tanggal 20 Maret 2019.

Tantri, S. N., \& Irmawati, P. (2018). Analisis Kinerja Anggaran Belanja Pada Dinas Kebudayaan Daerah Istimewa Yogyakarta Tahun 20122016. Jati: Jurnal Akuntansi Terapan Indonesia, 1(1), 27-37.

Nugeraha, 2016. Analisis Perbandingan Kinerja Keuangan Sebelum Dan Sesudah Diberlakunya Tax Amnesty Periode Pertama Pada Perusahaan Property Dan Real EState Yang Terdaftar Di BEI. Jurnal Distribusi Vol. 4, No. 1. Diakses pada Tanggal 20 Maret 2019.

Halim, Abdul, Icuk Rangga Bawono, Amin Dara, 2018. Perpajakan . Salemba Empat. Jakarta.

Hery, 2017. Teori Akuntansi. PT. Gramedia. Jakarta.

Pohan, chairil anwar, 2017. Perpajakan Indonesia. Mitra wacana Media. Jakarta

Resmi, Siti, 2019. Perpajakan. Salemba Empat. Jakarta Sugiono, 2016. Metode penelitian kuantitatif, kualitatif dan R\&D. Cv. Alfabeta, Jakarta 